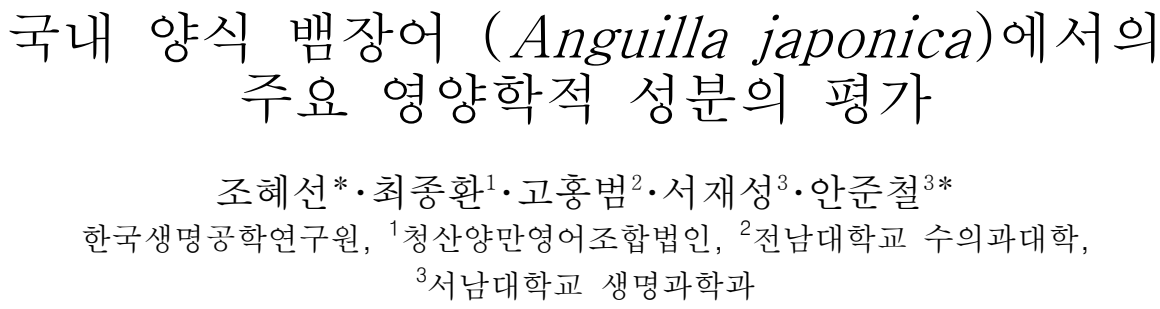

\title{
Evaluation of Major Nutrients of Domestic Farmed Eels Anguilla japonica
}

\author{
Hye Sun Cho*, Jong Hwan Choi ${ }^{1}$, Hong Beom $\mathrm{Ko}^{2}$, \\ Jae Sung $\mathrm{Seo}^{3}$ and Jun Cheul $\mathrm{Ahn}^{3 *}$ \\ Plant Systems Engineering Research Center, Korea Research Institute \\ of Bioscience and Biotechnology, Daejeon 305-806, Korea \\ ${ }^{1}$ Cheongsan Eel Culture Association \& Cheongsan Distribution Co., Yeonggwang-gun, Korea \\ ${ }^{2}$ College of Veterinary Medicine, Chonnam National University, Kwangju 500-757, Korea \\ ${ }^{3}$ Department of Biological Science, Seonam University, Namwon 590-711, Korea
}

To evaluate the proximate composition and main nutritive ingredients (vitamin $A, V_{A}$; vitamin $E, V_{E}$; cholesterol; the composition of fatty acids) between eels cultured in different domestic eel farms, we analyzed edible parts of eels that were cultured in three "Water Recirculation System (WRS)" farms and three "Still-Water System (SWS)" farms. We found differences in crude protein, crude lipids and the ash content of eel meat between the farms, but water content showed no significant difference. $V_{A}$ and $V_{E}$ contents did not show meaningful differences between the two culture methods, but there was a noticeable distinction between the eel farms. In particular, $\mathrm{V}_{\mathrm{E}}$ content showed significant differences between the eels of each farm (highest farm, about $25 \mathrm{mg} / 100 \mathrm{~g}$ dry wt; lowest farm, about $1 \mathrm{mg} / 100 \mathrm{~g}$ dry wt). The fatty acids of cultured eels were composed of monoenes (MUFA, 55-60\%), saturates (SFA, 30-33\%), $\omega-6$ highly unsaturates (HUFA, 1.6-2\%) and $\omega-3$ HUFA (8-9.2\%). The MUFA content of WRS eels $(59.9 \pm 1.97 \%)$ was higher than that of SWS eels $(55.8 \pm 0.48 \%)$. The contents of other fatty acids were higher in SWS eels (SFA, $33.0 \pm 0.52 \%$; $\omega$-6FUFA, $1.98 \pm 0.2 \%$; $\omega-3$ HUFA, $9.2 \pm 0.67 \%$ ) than in WRS eels (SFA, $30.5 \pm 1.34 \%$; $\omega-6$ HUFA, $1.62 \pm 0.19 \%$; $\omega-3$ HUFA, $8.0 \pm 0.5 \%$ ).

Key words: Anguilla japonica, Vitamin A, Vitamin E, Cholesterol, Fatty acids

\section{서 론}

뱀장어 (Anguilla japonica)는 다른 어종에 비해서 단백질, 지방, 무기질, 비타민 등이 풍부하게 함유되어 있는 대표적인 담수어종으로 한국, 일본, 중국 등 동남아시아에서는 기호식 품으로 오래 전부터 애용되어왔다. 이러한 민물 뱀장어는 자 연체포를 넘어서는 수요 때문에 일본과 대만을 시작으로 양식 이 이루어졌으나, 점차 가격 경쟁력이 원인으로 중국이 주요 생산국으로 올라선 바 있고 현재도 일본, 대만, 우리나라 등지 에서 주요 내수면 양식어종이 되고 있다. 하지만, 종묘의 자연 체포 의존에 따른 양식규모 확대의 한계, 치어 값 상승에 따른 생산비의 증가, 생산비 절감을 위한 밀식양식 및 급속생장 목적의 인공 첨가제의 빈번한 사용 등 타 수산물에 비하여 상대적으로 어려운 양식 환경에 처해있다.

뱀장어 양식의 가장 큰 해결책으로 기대되는 인공종묘의 생산은 1974년 일본의 Yammamoto와 Yamauchi가 인공배란 과 일부 치어의 배양에 성공한 사례에도 불구하고 여전히

\footnotetext{
*Corresponding author: secmeta2@yahoo.com and hscho@kribb.re.kr
}

상업적 규모의 인공종묘 생산은 이루어지고 있지 못한 실정이 다 (Tanaka et al., 1997; Ohta and Tanaka, 1997; Kim et al., 2007; Kagawa et al., 2009). 하지만, 최근 일본의 수산종합연구 센터 양식연구소에서는 인위적인 호르몬 주입으로 수정율 $70 \%$, 부화율에서 $50 \%$ 에 이르고 아직 낮은 숫자이지만 형태변 화를 완료한 인공 뱀장어 치어를 생산하고 있다 (NFDRI, 2007). 한편, 국내의 뱀장어 양식 현장에서는 뱀장어 양식산업 에서의 생산비 상승에 대한 대안으로 생산비 절감 및 양식효 율을 개선하기 위하여 양식방법의 변화 즉, 기존의 지수식 시설에서 고밀도 순환여과식 사육방식으로의 변경이 이루어 지고 있다. 일반적으로 지수식 양식은 일정량의 물을 사육지 에 채운 후 증발이나 침투 등에 의해 감소되는 수량만을 보충 해주거나 수질의 변화를 고려하여 필요시 새로운 물을 주수해 주는 방식으로 초기 시설비가 적게 드는 장점과 적정한 온도 를 년 중 유지하기가 어려워 일반적으로 생육기간이 길다는 단점을 갖는다. 반면에, 순환여과식은 좁은 면적에 고밀도 양식을 위해 인위적으로 산소를 공급하고 대사노폐물을 여과 하여 사용한 물을 버리지 않고 계속 사용하는 방식으로 초기 
설비비는 높지만, 생육기간이 상대적으로 짭아 전체적으로는 뱀장어 생산비를 감소시키는 효과를 얻는다. 그 외, 사료 증체 율의 효율개선, 폐사율감소를 위한 면역강화 목적의 기능성 사료 첨가제 개발 등을 비롯하여, 고품질 브랜드 뱀장어의 개발로 부가가치를 향상시키려는 시도도 이루어지고 있다 (Choi et al., 2002; Han, 2003; Bae et al., 2008).

국내에서 뱀장어 양식은 2010년 기준 양식장 약 500곳, 7,500 톤의 생산규모와 생산총액 약 1,900 억에 이르고 있으며, 배합사료의 시장 역시 약 900 억 규모로 성장하고 있다 (MOMAF, 2011). 하지만, 이러한 양적인 성장에도 불구하고 여전히 양식장 간 규모와 시설의 차이를 비롯한 물리 - 화학적 양식 환경의 차이가 여전하고 특히 지수식에서 순환여과식으 로의 국내의 뱀장어 시설이 전환되어가는 시점에서 지수식과 순환여과식으로 각각 양식하는 양식장 내 성만 뱀장어 육의 몇 가지 영양성분을 비교 - 평가하여 양식뱀장어의 성분 표준 화 및 고품질 양식뱀장어를 개발하기 위한 기초자료로 활용하 고자 하였다.

\section{재료 및 방법}

공시재료

전라남 - 북도 영암군, 영광군 및 고창군에 소재하는 지수 식 양식장 3곳과 순환여과식 양식장 3곳에서 양식 뱀장어 (Anguilla japonica) 각 3마리 (300 g-350 g)를 무작위로 추출하 고 머리, 내장 및 뼈를 제거한 뱀장어 육 만을 분쇄한 후 분석시 료로 사용하였다. 분석을 위한 시료는 2010년 8월 20일 각 양식장에서 수거한 시료를 이용하였으며, 각 양식장별 시료 뱀장어 치어의 입식시기, 양식조건 및 양식기간 등 양식장별 차이는 고려하지 않았다.

일반성분 분석

일반성분 (수분, 조단백, 조지방, 회분)은 $\mathrm{AOAC}$ (1995)에 준하여 분석하였다. 지방 및 수분 함량은 $\mathrm{CEM}$ 자동추출장치 (Labwave 9000/FAS 9001, CEM Corp., Matthews, NC, USA)를 이용하여 측정하였다. 단백질은 Kjeltec System (Kjeltec Auto 2400/2460, Foss Tecator AB, Höganas, Sweden)을 이용하여 분석하였으며, 회분은 회분분석기 (Mas 7000, CEM Corp., Mattews, NC, USA)를 이용하여 측정하였다.

비타민 A, E 분석

마쇄 건조한 장어 전어체 $0.5 \mathrm{~g}$ 을 $95 \%$ 에탄올 $(\mathrm{EtOH}) 3$ $\mathrm{ml}$ 과 pyrogallol $10 \% / \mathrm{EtOH} 0.5 \mathrm{ml}$ 을 섞어 잘 섞는다. 여기에 $1 \mathrm{ml} 50 \% \mathrm{KOH}$ 용액을 더하고 $95^{\circ} \mathrm{C}$ 수욕조에서 30 분 동안 비누화한 다음 얼음을 이용하여 급속 냉각하였다. 냉각된 시 료에 $3 \mathrm{ml}$ 의 증류수와 석유에테르를 넣고 잘 섞은 다음 석유에 테르 층만을 회수하는 과정을 3회 반복하고 회수된 석유에테 르 층은 무수 $\mathrm{Na}_{2} \mathrm{SO}_{4}$ 를 사용하여 수분을 제거한 다음 회전농 축기를 사용하여 농축하였다. 농축액은 비타민 $\mathrm{A}$ 분석을 위해 서는 $1 \mathrm{ml}$ isopropyl alcohol에, 비타민 $\mathrm{E}$ 분석을 위해서는 1 $\mathrm{ml}$ hexane 용액 각각 용해시킨 다음 $0.2 \mu \mathrm{M}$ pore membrane filter를 사용하여 여과한 다음 HPLC 분석에 이용하였다. HPLC 분석 컬럼은 $\mu$-Porasil column $(4.6 \times 250 \mathrm{~nm}$, Waters, USA), 이동상으로는 n-hexane:isopropanol (99.92:0.08, v/v, isocratic mode)를 $1 \mathrm{ml} / \mathrm{min}$ 의 flow rate로, 그리고 검출은 UV/VIS 검출기 (Waters Model 2489, USA)를 사용하여 $\mathrm{V}_{\mathrm{A}}$ 는 $336 \mathrm{~nm}, \mathrm{~V}_{\mathrm{E}}$ 는 $280 \mathrm{~nm}$ 의 조건으로 수행하였다.

\section{콜레스테롤분석}

마쇄 건조한 장어 전어체 $1 \mathrm{~g}$ 에 $3 \mathrm{ml} \mathrm{95 \%} \mathrm{EtOH}$ 을 넣고 30 분간 초음파추출을 하였다. 추출액에 $50 \% \mathrm{KOH}$ 용액 $1 \mathrm{ml}$ 을 첨가하고 $50^{\circ} \mathrm{C}$ 에서 1 시간 동안 incubation한 다음 얼음 위에서 냉각하였다. $5 \mathrm{ml}$ hexane을 첨가하고 5 분간 섞은 후 상층 (유기 층) $1 \mathrm{ml}$ 만을 취한 후 $\mathrm{N}_{2}$ gas 하에서 농축하였다. 농축액은 $3 \mathrm{ml}$ Libermann-Burchad 시약을 첨가하고 vortex 하여 실온에 서 30 분 정치한 후 $640 \mathrm{~nm}$ 에서 흡광도를 측정하였다.

\section{지방산 분석}

마쇄 건조한 전어체에서 시료를 채취하여 Folch et al. (1957) 의 방법에 따라 지질을 추출하였으며, Morrison and Smith (1964)의 방법에 준하여 메틸화한 후 상층액을 분리하여 $-80^{\circ} \mathrm{C}$ 에 보관하였으며, 자동 시료 주입기가 장착된 기체 크로마토 그래피 (Varian 3400, USA)를 이용하여 분석하였다. 분석에 사용된 기기의 조건은 Table 1 에서 보는 바와 같다.

Table 1. Condition of gas chromatography for fatty acid analysis

\begin{tabular}{ll}
\hline \multicolumn{1}{c}{ Items } & \multicolumn{1}{c}{ Condition } \\
\hline Instrument & Varian star 3400. USA \\
Column & Supercowax $10,30 \mathrm{~m} \times 0.53 \mathrm{~mm} \mathrm{ID}$, \\
& $1.0 \mu \mathrm{m}$ film thickness \\
Detector & Flame lonization Detector \\
Carrier gas & Nitrogen $(99.99 \%$, Research purity) \\
Injection port temperature & $210^{\circ} \mathrm{C}$ \\
Column temperature & $\left.165^{\circ} \mathrm{C}, 2 \mathrm{~min}\right)$ to $240^{\circ} \mathrm{C}$ at $3^{\circ} \mathrm{C}$ min \\
Detector port temperature & $240^{\circ} \mathrm{C}$ \\
Injection volume & $1.0 \mu \mathrm{l}$ \\
\hline
\end{tabular}

Table 2. The comparison of proximate compositions of eels cultured at different farm of two types of culture methods, still-water system and water recirculation system

\begin{tabular}{lccccc}
\hline Culture typea & Farm Nob & $\begin{array}{c}\text { Moisture } \\
(\%)\end{array}$ & $\begin{array}{c}\text { Crude Protein } \\
(\%)\end{array}$ & $\begin{array}{c}\text { Crude lipid } \\
(\%)\end{array}$ & $\begin{array}{c}\text { Ash } \\
(\%)\end{array}$ \\
\hline Still-Water & $\mathrm{A}$ & $63.3 \pm 1.42$ & $17.4 \pm 0.3$ & $18.6 \pm 0.9$ & $1.2 \pm 0.1$ \\
System & $\mathrm{B}$ & $62.6 \pm 1.8$ & $17.4 \pm 1.0$ & $17.4 \pm 0.7$ & $1.2 \pm 0.0$ \\
& $\mathrm{C}$ & $61.9 \pm 0.6$ & $16.9 \pm 0.74$ & $16.9 \pm 0.5$ & $1.2 \pm 0.0$ \\
\hline \multirow{4}{*}{ Water } & Mean & $62.6 \pm 1.3$ & $17.2 \pm 0.7$ & $17.7 \pm 0.7$ & $1.2 \pm 0.0$ \\
Recirculation & $\mathrm{A}$ & $62.9 \pm 1.0$ & $16.7 \pm 0.7$ & $18.7 \pm 0.2$ & $1.1 \pm 0.1$ \\
System & $\mathrm{B}$ & $62.5 \pm 0.3$ & $16.7 \pm 0.3$ & $18.1 \pm 0.4$ & $1.2 \pm 0.1$ \\
& $\mathrm{C}$ & $62.6 \pm 2.3$ & $16.0 \pm 2.0$ & $19.0 \pm 1.1$ & $1.0 \pm 0.2$ \\
\cline { 2 - 6 } & Mean & $62.7 \pm 1.2$ & $16.5 \pm 1.0$ & $18.6 \pm 0.8$ & $1.1 \pm 0.1$ \\
\hline
\end{tabular}

${ }^{\mathrm{a}}$ The type for eel culture. ${ }^{\mathrm{b}} \mathrm{Eel}$ farm locations in which eel were used for analysis in this experiment. A, Chonramam-do Yeongam-gun; B, C and D, Chonrabuk-do Gochang-gun; E and F, Chonranam-do Yeonggwang-gun. All tests are performed by three replicates. 


\section{결과 및 고찰}

국내 뱀장어 양식장에서 양식된 뱀장어육 내 주요 영양학적 성분의 비교평가를 위하여 전라남 - 북도에 소재한 뱀장어 양식장 중 지수식 3 곳과 순환여과식 3 곳의 양식장 6 곳을 임의 로 선택하여 동일한 크기 (3 미 $/ \mathrm{kg}$ ) 뱀장어 육의 일반성분을 분석하였다 (Table. 2). 양식장별 뱀장어육의 수분함량은 $61.9 \%-63.3 \%$, 조단백질은 $16.0 \%-17.44 \%$, 조지방은 $16.9 \%$ $18.9 \%$ 그리고 조회분은 $1.0 \%-1.24 \%$ 의 분포를 나타냈다. 지수 식과 순환여과식 양식장을 구분한 평균값은 수분함량 (지수 식, $61.9 \pm 1.3$; 순환여과식, $62.7 \pm 1.2$ ), 조단백 (지수식, 17.2 \pm 1.3 ; 순환여과식, $16.5 \pm 1.0$ ), 조지방 (지수식, $17.7 \pm 0.7$; 순환여과식, $18.6 \pm 0.8$ ) 및 회분 (지수식, $1.2 \pm 0.0$; 순환여과식, $1.1 \pm 0.1$ )로 구분되었지만 두 양식방식에서의 이들 값은 유의한 상관관계 를 나타내지 않았다 $(P>0.05)$. 한편, 뱀장어를 포함한 양식어 류의 자연산과 양식산의 비교에서 자연산이 수분, 조단백질 함량이 다소 높고 조지방과 회분 함량은 양식산이 다소 높아, 자연산에서의 높은 조단백질과 양식산에서의 높은 조지방 함량은 양식동안의 높은 지방질 함유사료 (뱀장어 사료 3.0\% 이상) 및 성장조건의 차이에 기인한 것으로 고려되고 있다 (Kim et al., 1995; Kim et al., 2000). 물론 이러한 일반성분은 성장과 산란 등 생육시기에 따른 증감도 있는 것으로 알려져 있다 (Kim et al., 2000; Hirano et al., 1980). 본 연구에서 사용한 뱀장어육 시료가 동일한 시기와 동일한 크기의 출하용 성만뱀 장어 시료임을 고려하면, 양식장별 뱀장어의 일반성분의 조함 량은 큰 차이를 보이지 않으며, 나아가 지수식과 순환여과식 양식방식에서의 유의적 차이 역시 없었다.

뱀장어의 대표적인 영양성분으로 비타민 $\mathrm{A}\left(\mathrm{V}_{\mathrm{A}}\right.$, retinol)의 함량을 비교하였다 (Fig. 1). 자연산 뱀장어의 $\mathrm{V}_{\mathrm{A}}$ 함량은 일반 적으로 $1,000 \mu \mathrm{g}$ (약 3,500 IU)/g D.W. 정도 함유하는 것으로 알려져 있지만 (Cho et al., 2006), Anguilla 종에 따른 차이를

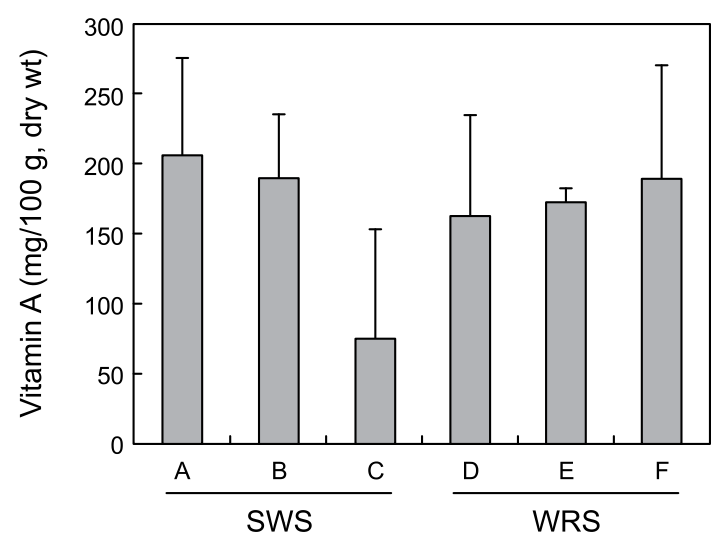

Fig. 1. The comparison of vitamin A contents from eels cultured by two different culture methods, SWS (still-water system) and WRS (water recirculation system), respectively. Locations of each farm are as follows. A, Chonranam-do, Yeongam-gun; B, C and D, Chonrabuk-do, Gochang-gun; $\mathrm{E}$ and $\mathrm{F}$, Chonranam-do, Yeonggwang-gun. All tests are performed by three replicates.

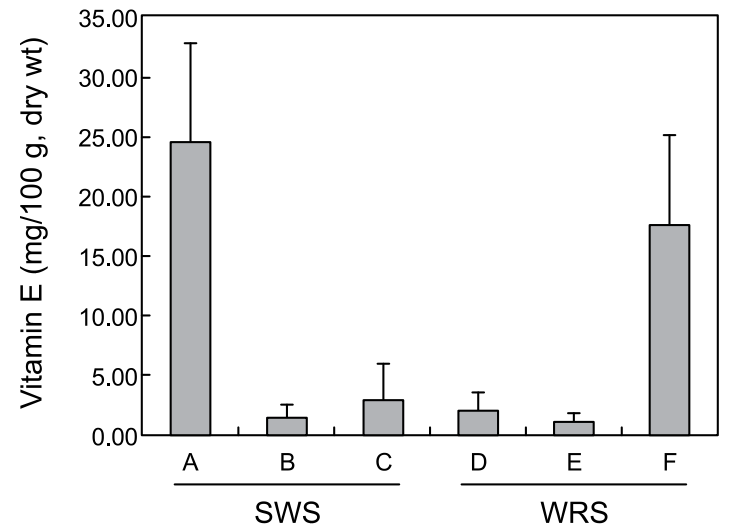

Fig. 2. The comparison of vitamin E (tocopherol) contents from eels cultured by two different culture methods, SWS (still-water system) and WRS (water recirculation system), respectively. Locations of each farm are as follows. A, Chonranam-do, Yeongam-gun; B, C and D, Chonrabuk-do, Gochang-gun; E and F, Chonranam-do, Yeonggwang-gun. All tests are performed by three replicates.

보이고 개체의 크기가 커질수록 함량은 증가하였다 (Edisbury et al., 1937). 한편, 동일한 크기의 개체를 분석한 본 실험결과 에서도 개체 간 $\mathrm{V}_{\mathrm{A}}$ 함량의 차이가 커 $\mathrm{V}_{\mathrm{A}}$ 의 뱀장어 육내 축적은 개체차도 다소 있는 것으로 사료되었다. 반면에 지수식과 순 환여과식 간 $\mathrm{V}_{\mathrm{A}}$ 함량에서는 유의적인 큰 차이를 보이지 않았 으며, 오히려 양식장간 차이가 현저하여, 예로 양식장 A (지수 식, $206 \pm 125 \mu \mathrm{g} / 100 \mathrm{~g}$, dry wt)와 양식장 C (지수식, $74.7 \pm 79.2$ $\mu \mathrm{g} / 100 \mathrm{~g}, \mathrm{dry} \mathrm{wt}$ )의 차이를 보여 두 가지 양식방법에서의 차이는 크지 않고 사료를 포함한 양식환경이 $\mathrm{V}_{\mathrm{A}}$ 의 체내함량 에 영향을 주는 요인으로 사료되었다. Figure 2는 동일시료에 서 비타민 $\mathrm{E}\left(\mathrm{V}_{\mathrm{E}}\right.$, tocopherol)의 함량을 비교한 것이다. 자연산 뱀장어에서의 $\mathrm{V}_{\mathrm{E}}$ 함량은 일반적으로 $4-7 \mathrm{mg} / 100 \mathrm{~g}$ dry wt으로 알려져 있으며, 일본에서 일본산 양식 뱀장어 (Anguilla japonica)의 근육내 함량은 21-37 mg/100 g, dry wt로 양식 뱀장어의 품질을 결정하는 주요 지표성분으로서의 역할을 한다 (Furuta et al., 2009). $\mathrm{V}_{\mathrm{A}}$ 와 마찬가지로 $\mathrm{V}_{\mathrm{E}}$ 역시 양식장간 차이가 크고 양식방법에의 차이는 유의적 의미를 찾기 어려웠 다. 특히 $\mathrm{V}_{\mathrm{E}}$ 는 $\mathrm{V}_{\mathrm{A}}$ 에 비교하여 양식장간 차이가 현저하였으며, 지수식 양식장 A $(24.6 \pm 17.2 \mathrm{mg} / 100 \mathrm{~g}$, dry wt)와 순환여과식 양식장 $\mathrm{F}(17.6 \pm 8.9 \mathrm{mg} / 100 \mathrm{~g}$, dry wt)는 지수식 양식장 $\mathrm{B}$ $(1.34 \pm 0.98 \mathrm{mg} / 100 \mathrm{~g}$, dry wt)와 C $(2.83 \pm 3.33 \mathrm{mg} / 100 \mathrm{~g}$, dry $\mathrm{wt})$, 순환여과식 양식장 $\mathrm{D}(1.92 \pm 1.41 \mathrm{mg} / 100 \mathrm{~g}$, dry wt)와 $\mathrm{E}(1.01 \pm 0.26 \mathrm{mg} / 100 \mathrm{~g}$, dry wt $)$ 에 비교하여 현저하게 높은 함량을 나타내었다. 이러한 양식장간 $\mathrm{V}_{\mathrm{E}}$ 의 현저한 차이는 두 가지 대표적인 양식방법에서의 차이라기 보다는 양식장별 차이를 갖는 다른 요인에 기인한다는 것을 의미한다. 한편, 양식 뱀장어 육에 함유된 $\mathrm{V}_{\mathrm{E}}$ (tocopherol)는 대부분 $\mathrm{a}$ -tocopherol이고 극히 소량의 $\beta$-tocopherol로 구성되었다 (Fig. 3). 요약하면, 장어육에 함유된 지용성 비타민 $\mathrm{V}_{\mathrm{A}}$ 와 $\mathrm{V}_{\mathrm{E}}$ 는 동일 양식환경 내에서도 개체차가 비교적 크게 나타나지만 지수식 
Table 3. The fatty acids compositions in total lipids from eels cultured by two different culture methods, SWS (still-water system) and WRS (water recirculation system), respectively

\begin{tabular}{|c|c|c|c|c|c|c|}
\hline \multirow{2}{*}{$\begin{array}{c}\text { Fatty acids (\%) } \\
\text { (Carbon No.:double bond) }\end{array}$} & \multicolumn{3}{|c|}{ Still-Water System } & \multicolumn{3}{|c|}{ Water Recirculation System } \\
\hline & $A^{a}$ & $\mathrm{~B}$ & C & $\mathrm{D}$ & $E$ & $\mathrm{~F}$ \\
\hline Saturates $^{\mathrm{b}}$ & 32.8 & 33.6 & 32.7 & 30.4 & 29.3 & 31.9 \\
\hline Mean $^{c}$ & & $33.0 \pm 0.52$ & & & $30.5 \pm 1.34$ & \\
\hline Myristic acid (C14:0) & $3.4 \pm 0.3$ & $3.6 \pm 0.4$ & $3.2 \pm 0.1$ & $3.1 \pm 01$ & $3.3 \pm 0.2$ & $3.4 \pm 0.2$ \\
\hline Palmitic acid (C16:0) & $23.5 \pm 0.4$ & $24.6 \pm 0.8$ & $23.7 \pm 0.9$ & $21.4 \pm 0.4$ & $21.4 \pm 0.3$ & $22.1 \pm 0.7$ \\
\hline Stearic acid (C18:0) & $6.05 \pm 0.2$ & $5.7 \pm 0.2$ & $5.8 \pm 0.3$ & $5.9 \pm 0.6$ & $4.6 \pm 0.2$ & $6.4 \pm 0.8$ \\
\hline Monoenes & 55.2 & 55.8 & 56.2 & 59.6 & 61.9 & 58.0 \\
\hline Mean & & $55.8 \pm 0.5$ & & & $59.9 \pm 2.0$ & \\
\hline Palmitoleic acid (C16:1n7) & $6.0 \pm 0.2$ & $7.2 \pm 0.2$ & $6.4 \pm 0.3$ & $6.3 \pm 0.5$ & $7.5 \pm 0.3$ & $6.2 \pm 0.4$ \\
\hline Vaccenic acid (C18:1n7) & $2.0 \pm 0.2$ & $2.5 \pm 0.5$ & $2.2 \pm 0.1$ & $2.2 \pm 0.1$ & $2.2 \pm 0.0$ & $2.3 \pm 0.2$ \\
\hline Oleic acid (C18:1n9) & $42.8 \pm 0.7$ & $43.2 \pm 0.3$ & $45.0 \pm 0.2$ & $48.3 \pm 0.6$ & $50.1 \pm 0.7$ & $46.9 \pm 1.9$ \\
\hline Eicosenoic acid (C20:1n9) & $4.5 \pm 0.1$ & $3.0 \pm 0.3$ & $2.6 \pm 0.1$ & $2.8 \pm 0.1$ & $2.2 \pm 0.4$ & $2.7 \pm 0.4$ \\
\hline Highly Unsaturates (n-6) & 2.1 & 1.8 & 2.1 & 1.7 & 1.4 & 1.7 \\
\hline Mean & & $2.0 \pm 0.2$ & & & $1.6 \pm 0.2$ & \\
\hline Linoleic acid (C18:2n6) & $1.4 \pm 0.1$ & $0.9 \pm 0.1$ & $1.2 \pm 0.1$ & $0.9 \pm 0.1$ & $0.6 \pm 0.0$ & $0.9 \pm 0.2$ \\
\hline$\gamma$-Linoleic acid $(\mathrm{C} 18: 3 \mathrm{n} 6)$ & $0.1 \pm 0.0$ & $0.2 \pm 0.1$ & $0.2 \pm 0.1$ & $0.1 \pm 0.0$ & $0.1 \pm 0.0$ & $0.1 \pm 0.0$ \\
\hline Docosatetraenoic acid (C22:4n6) & $0.3 \pm 0.0$ & $0.3 \pm 0.0$ & $0.2 \pm 0.0$ & $0.2 \pm 0.0$ & $0.2 \pm 0.0$ & $0.2 \pm 0.1$ \\
\hline Arachidonic acid (C20:4n6) & $0.4 \pm 0.0$ & $0.4 \pm 0.1$ & $0.4 \pm 0.1$ & $0.5 \pm 0.0$ & $0.5 \pm 0.0$ & $0.5 \pm 0.1$ \\
\hline Highly Unsaturates (n-3) & 9.9 & 8.6 & 9.2 & 8.3 & 7.4 & 8.3 \\
\hline Mean & & $9.2 \pm 0.7$ & & & $8.0 \pm 0.5$ & \\
\hline Linolenic acid (C18:3n3) & $0.32 \pm 0.0$ & $0.22 \pm 0.0$ & $0.24 \pm 0.0$ & $0.20 \pm 0.0$ & $0.14 \pm 0.0$ & $0.23 \pm 0.0$ \\
\hline Eicosapentaenoic acid (C20:5n3) & $1.63 \pm 0.1$ & $1.93 \pm 0.3$ & $1.81 \pm 0.2$ & $1.76 \pm 0.1$ & $1.73 \pm 0.2$ & $1.75 \pm 0.2$ \\
\hline Docosahexaenoicacid (C22:6n3) & $7.94 \pm 0.5$ & $6.40 \pm 0.35$ & $7.10 \pm 0.6$ & $6.32 \pm 0.1$ & $5.55 \pm 0.5$ & $6.34 \pm 0.7$ \\
\hline
\end{tabular}

${ }^{\mathrm{a}}$ Locations of each farm are as follows. A, Chonranam-do, Yeongam-gun; B, C and D, Chonrabuk-do, Gochang-gun; E and F, Chonranam-do, Yeonggwang-gun. ${ }^{\text {b }}$ Values are mean of applicable $\%$ fatty acid contents and standard deviations are omitted. ${ }^{c}$ Values are mean of 3 values on still-water system and water recirculation system, respectively. All tests are performed by three replicates.

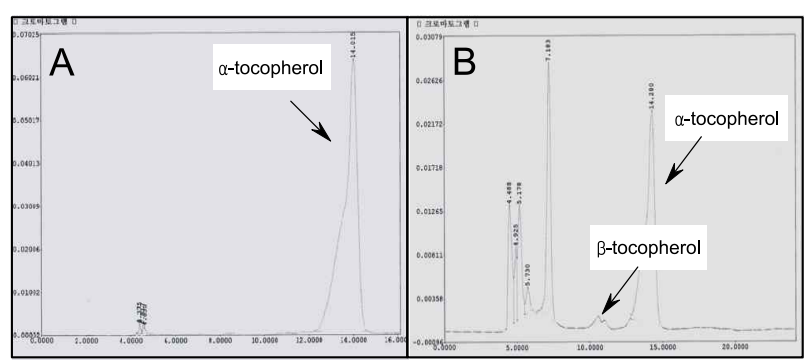

Fig. 3. Vitamin E (tocopherol) analysis from edible meat of cultured eels. A, HPLC chromatogram of standard a -tocopherol; B, HPLC chromatogram of sample extracted from cultured eel.

과 순환여과식에 따른 양식방법에 의한 유의적 영향은 없는 것으로 보이고 오히려 각 양식장에서의 기타 양식방법, 예로 배합사료 종류, 수질관리 차이, 미생물 사용여부 혹은 미생물 종류 및 비타민 제제의 첨가 등에 크게 영향을 받는 것으로 보였다. Fig. 4는 동일시료에서 고지방 식품인 뱀장어 육내 주요 영양성분 중 하나인 콜레스테롤 함량을 비교하였다. $\mathrm{V}_{\mathrm{A}}$, $\mathrm{V}_{\mathrm{E}}$ 와 마찬가지로 양식장 간에 함량의 차이를 나타내고 있어,

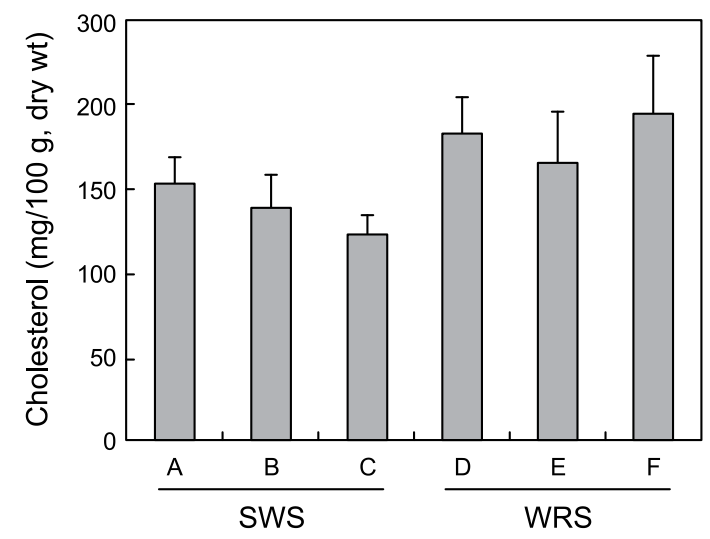

Fig. 4. The comparison cholestrol contents from eels cultured by two different culture methods, SWS (still-water system) and WRS (water recirculation system), respectively. Locations of each farm are as follows. A, Chonranam-do, Yeongam-gun; B, C and D, Chonrabuk-do, Gochang-gun; $\mathrm{E}$ and $\mathrm{F}$, Chonranam-do, Yeonggwang-gun. All tests are performed by three replicates.

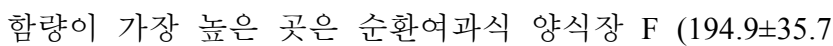


$\mathrm{mg} / 100 \mathrm{~g}$ dry wt)이고, 가장 낮은 곳은 지수식 양식장 C (121.9 $\pm 8.2 \mathrm{mg} / 100 \mathrm{~g}$ dry wt )였다. 하지만 $\mathrm{V}_{\mathrm{A}}, \mathrm{V}_{\mathrm{E}}$ 와는 달리 양식 뱀장어육 내 콜레스테롤 함량은 두 가지 양식방법 간에 유의 적인 차이 (지수식 평균값, $140.412 .0 \mathrm{mg} / 100 \mathrm{~g}$ dry wt; 순환여 과식 평균값, $181.3 \pm 15.0 \mathrm{mg} / 100 \mathrm{~g} \mathrm{dry} \mathrm{wt}$ 를 나타내었다. 이는 콜레스테롤의 뱀장어육 내 축적은 $\mathrm{V}_{\mathrm{A}}, \mathrm{V}_{\mathrm{E}}$ 와는 달리 사육방식 에 따른 차이를 나타낼 수 있으며, 이는 지수식에 비교하여 순환여과식에서 사육되는 뱀장어의 환경적 차이와 높은 조지 방함량 (Table 2)과 연관성이 있는 것으로 사료된다. 일반적으 로 어류의 지질함량과 콜레스테롤 함량은 비례하는 경향을 보이는 것으로 알려져 있으며, 유사한 크기의 우리나라 자연 서식 뱀장어에서의 지방산함량은 약 $20.4 \%$ 로 콜레스테롤 함 량은 $249.3 \mathrm{mg} / 100 \mathrm{~g}$ dry wt로 보고 된 바 있다 (Jeong et al., 1998).

양식뱀장어 가식부 내 지방산 중 포화지방산 (saturated fatty acids, SFA), 단불포화지방산 (monounsaturated fatty acids, MUFA) 그리고 고도불포화지방산 (highly unsaturated fatty acids, HUFA)인 $\omega-6$ 와 $\omega-3$ 지방산 등을 비교하였다 (Table 3). SFA는 지수식 3곳의 평균 구성비 $(33.0 \pm 0.5 \%)$ 가 순환여과 식의 평균 $(30.5 \pm 1.3 \%)$ 보다 $8,2 \%$ 높은 구성을 보였다. MUFA 는 순환여과식 $(59.9 \pm 2.0)$ 이 지수식 $(55.8 \pm 0.5 \%)$ 보다 $7.4 \%$ 높 았으며, $\omega-6$ 와 $\omega-3$ 지방산을 포함하는 HUFA는 지수식 $(9.2$ $\pm 0.7 \%)$ 이 순환여과식 $(8.0 \pm 0.5 \%)$ 보다 $15 \%$ 높은 구성을 보였 다. SFA는 palmitic acid (지수식, 23.9 \pm 0.6 ; 순환여과식, 21.6 \pm 0.4 ), MUFA는 oleic acid (지수식, $43.7 \pm 1.17 \%$ 순환여과식, $48.4 \pm 1.6 \%$ ), HUFA는 docosahexanoicacid (지수식, $7.2 \pm 0.8 \%$ 순환여과식, $6.1 \pm 0.5 \%$ )가 각각 가장 높은 구성을 보였다. 이러 한 결과는 Hong et al. (2005)이 보고한 양식뱀장어 (체중 380 $-420 \mathrm{~g}$ )의 뱀장어육 내 지방산이 SFA, $32.0 \%$; MUFA, $55.0 \%$; HUFA, $13.1 \%$ 등으로 분포하고 있다는 보고와 비교하면 아마 분석대상 뱀장어 크기에 기인한 HUFA 구성비에서의 차이를 제외하고는 거의 유사한 수치를 보인 것으로 간주된다. 한편, 국내 자연산/양식산 뱀장어 지방산 구성에 대한 연구는 Choi et al. (1984)이 자연산 (SFA, 32.67\%; MUFA, 48.4\%, HUFA, $20.3 \%$ )과 양식산 (SFA, 30.5\%; MUFA, 53.6\%, HUFA, $8.0 \%$ )으 로, 그리고 Jeon et al. (2003)은 지역별 자연산 뱀장어 $(200 \mathrm{~g}$ 이상)에서 SFA, 38.0-43.0\%; MUFA, 54.0-58.5\%; HUFA, $1.95-2.31 \%$ 의 지방산 구성을 보고한 바 있다. 따라서 자연산이 라고 하더라도 채집시기, 장소, 크기 등에 따라 지방산 구성에 차이가 있을 수 있고, 양식 뱀장어 역시 먹이와 배양환경에 따라 지방산의 구성비가 바뀐다는 점에서 사료 또는 사육환경 의 인위적 조정으로 지방산 함량 또는 지방산 구성비를 조정 할 수 있는 가능성도 있는 것으로 사료된다. 실제로, 사료의 필수 지방산인 리놀레산 $\left(\mathrm{C}_{18: 3}\right)$ 과 리놀산 $\left(\mathrm{C}_{18: 2}\right)$ 비율에 따라 뱀장어의 생장률 차이에 대한 보고가 있으며, 먹이에 포함된 사료 지방산의 구성요소 대비 뱀장어 가식부 지방산 비율을 통하여 사료성분에 포함된 $\omega-3$ HUFA가 뱀장어 HUFA 생합 성에 주도적으로 이용되는 것으로 보고된 바 있다 (Takeuchi et al., 1980; Choi et al., 1985). 따라서, 양식하는 뱀장어의 w-3 HUFA 비의 개선 혹은 일정한 품질을 얻기 위해서는 지속적인 사료 및 첨가제의 개발이 필요하고, 지수식 또는 순환여과식과 같은 양식환경이 뱀장어 체내 지방산 함량에 미치는 영향을 보다 면밀히 살펴볼 필요가 있을 것으로 사료 된다.

$$
\text { 사 사 }
$$

본 연구는 2010년 농림부의 수산기술개발과제 (과제번호 110086-3)의 지원에 의해 수행되었으며, 이에 감사드립니다.

\section{참고문헌}

AOAC. 1995. Official methods of analysis of the association of official analysis chemicals, 14th edition. Arlington. A.V., 1141.

Bae JY, Han K, Lee JH, Kim SE, Lee JY and Bai SC. 2008. Effects of dietary quartz porphyry and feed stimulants, BAISM supplementation on growth performance and disease resistance of juvernile eel Anguilla japonica. J. Aquaculture 21, 26-33.

Choi JH, Rhim CH, Bae TJ, Byun DS and Yoon TH. 1985. Studies on lipids in fresh-water fishes. 7. Comparison of lipid components among wild and cultured eel (Anguilla japonica), and conger eel (Astroconger myriaster). Bull Korean Fish Soc 18, 439-446

Choi JH, Ro JI and Pyeun JH. 1984. Studies on lipids in fresh-water fishes. 3. Distribution of lipid components in various tissues of eel, Anguilla japonica. Bull Korean Fish Soc 17, 477-484.

Choi YJ, Lee NJ, Cho YJ and Bai SC. 2002. Identification of feeding stimulants to improve efficiency of diet for flatfish. J Kor Fish Soc 35, 196-200.

Cho YJ, Jung HJ, Kim YC, Oh SM, Son MJ, Kim SM and Shim KB. 2006. Optimal process of eel hot-water for proper edible volume. J Fish Mar Sci Edu 18, 374-378.

Edisbury JR, Lovern JA and Morton RA. 1937. Distribution of vitamin A in the tissues of the eels Anguilla vulgaris and A. aucklandi Rich. Biochem J 31, 416-423.

Folch J, Lees M and Sloane-Stanley GH. 1957. A simple method for the isolation and purification of total lipids from animal tissue. J Biol Chem 226, 497-509.

Furuta H, Ishida T, Suzuki T, Unuma T, Kurokawa T, Sugita T and Yamamoto T. 2009. Vitamin content and quality of eggs produced by broodstock injected with vitamins $\mathrm{C}$ and $\mathrm{E}$ during ratified maturation in Japanese eel Anguilla japonica. Aquaculture 289, 
334-339.

Han YO. 2003. Synergistic effects of mineral dusts. J Miner Soc Kor 10, 1-17.

Hirano T, Nakamura H and Suyama M. 1980. Quality of wild and cultured ayu-II seasonal variation of proximate composition. Bull Japan Soc Fish 46, 75-78.

Hong SP, Kim SY, Jeong DY, Jeong PH and Shin DH. 2005. Mineral contents and fatty acid composition in bone and flesh of cultured eel. J Fd Hyg Safety 20, 98-102.

Jeong BY, Choi BD and Lee JS. 1998. Proximate composition, cholesterol and $\alpha$-tocopherol content in 72 species of Korean fish. J Kor Fish Soc 31, 160-167.

Jeon MJ, Han KM, Yoo JH, Lee KA and Bai SC. 2003. Nutritional properties of body composition based on captured location and size in wild eels, Anguilla japonica. J Aquaculture 16, 273-278.

Kagawa H, Kasuga Y, Adachi J, Nishi A, Hashimoto H, Imaizumi H and Kaji S. 2009. Effects of continuous administration of human chorionin gonadotropin, salmon pituitary extract, and gonadotropin-releasing hormone using osmotic pumps on induction of sexual maturation in male Japanese eel, Anguilla japonica. Aquaculture 296, 117-122.

Kim DJ, Kang EJ, Bae JY, park MW and Kim EO. 2007. Development of the eggs and pr-leptocephalus larvae by natural spawning of artificially-matured Japanese eel, Anguilla japonica. J. Aquaculture 20, 160-167.

Kim HY, Park CC, Lee HB, Ahn BJ, Hur JW, Lee SO and Cho DJ. 1995. Studies on the tastes compounds of wild and cultured fishes (II). The report of National Institute of Health 32, 647-666.
Kim HY, Shin JW, Sim GC, Park HO, Kim HS, Kim SM, Kim JS and Jang YM. 2000. Comparison of the taste compounds of wild and cultured eel, puffer and snake head. Korean J Food Technol 32, 1058-1067.

MOMAF, 2011. Ministry of Martime Affairs and Fisheries, Statistical Year Book of Martime Affairs and Fisheries. Seoul, Korea.

Morrison WR and Smith LM. 1964. Preparation of fatty acid methylesters and dimethylacetals from lipid with boron fluoride methanol. J Lipid Res 5, 600-608.

NFDRI, 2007. National Fisheries and Development Institute, Analysis Reports of Abroad Fisheries Trend. Busan, Korea.

Ohta H and Tanaka H. 1997. Relationship between serum levels of human chorionic gonadotropin (hCG) and 11-ketotestosterone after a single injection of hCG and induced maturity in the male Japanese eel, Anguilla japonica. Aquaculture 153, 123-134.

Takeuchi T, Arai S, Watanabe S and Shimma Y. 1980. Requirement of eel Anguilla japonica for essential fatty acids. Bull Japan Soc Sci Fish 46, 345-353.

Tanaka H, Okuzawa K, Iinuma N and Hirose K. 1997. Artificial induction of maturation and fertilization in the Japanese eel, Anguilla japonica. Fish Physiol Biochem 17, 163-169.

Yammamoto K and Yammauchi K. 1974. Sexual maturation of Japanese eel and production of eel larvae in the aquarium. Nature 251, 220-221.

2011년 3월 17일 접수

2011년 4월 25일 수정

2011년 5월 16일 수리 